\title{
Flour, Feed, or Grain Milling
}

National Cancer Institute

\section{Source}

National Cancer Institute. Flour, Feed, or Grain Milling. NCI Thesaurus. Code C156867.

An occupation involving the grinding of raw agricultural materials into products for farming or industrial applications. 